\title{
Assessment of silver-stained AFLP markers for studying DNA polymorphism in proso millet (Panicum miliaceum L.)
}

\author{
DÉCIO KARAM ${ }^{1,4}$, PHILIP WESTRA ${ }^{2}$, SCOTT J. NIESSEN ${ }^{2}$, SARAH M. WARD ${ }^{3}$ and \\ JOSÉ EDSON FONTES FIGUEIREDO ${ }^{1}$
}

(received: January 05, 2006; accepted: October 05, 2006)

\begin{abstract}
Assessment of silver-stained AFLP markers for studying DNA polymorphism in proso millet (Panicum miliaceum L.)). Proso millet (Panicum miliaceum L.) is a serious weed in North America. A high number of wild proso millet biotypes are known but the genetic basis of its phenotypic variation is poorly understood. In the present study, a non-radioactive silver staining method for PCR-Amplified Fragment Length Polymorphism (AFLP) was evaluated for studying genetic polymorphism in American proso millet biotypes. Twelve biotypes and eight primer combinations with two/three and three/three selective nucleotides were used. Pair of primers with two/three selective nucleotides produced the highest number of amplified DNA fragments, while pair of primers with three/three selective nucleotides were more effective for revealing more polymorphic DNA fragments. The two better primer combinations were EcoR-AAC/Mse-CTT and EcoR-ACT/Mse-CAA with seven and eleven polymorphic DNA fragments, respectively. In a total of 450 amplified fragments, at least 339 appeared well separated in a silver stained acrylamide gel and 39 polymorphic DNA bands were scored. The level of polymorphic DNA (11.5\%) using only eight pairs of primers were effective for grouping proso millet biotypes in two clusters but insufficient for separating hybrid biotypes from wild and crop. Nevertheless, the present result indicates that silver stained AFLP markers could be a cheap and important tool for studying genetic relationships in proso millet.
\end{abstract}

Key words - AFLP, genetic diversity, molecular markers, proso-millet

RESUMO - (Avaliação de marcadores AFLP corados com prata para estudar polimorfísmo de DNA em proso millet (Panicum miliaceum L.)). Proso millet (Panicum miliaceum L.) constitui uma séria praga agrícola na America do Norte. Grande número de biótipos de proso millet selvagens são conhecidos mas a base genética da variabilidade fenotípica é pouco conhecida. No presente estudo foi avaliado o método não radioativo, de coloração com prata, para visualizar fragmentos polimóficos de DNA amplificados por PCR (AFLP) visando estudo de polimorfísmo genético em biótipos de proso millet americano. Foram usados doze biótipos e oito combinações de primers com dois/três e três/três nucleotídeos seletivos. Pares de "primers" com dois/três nucleotídeos seletivos produziram maior número de fragmentos de DNA, enquanto que pares de "primers" com três/três nucleotídeos seletivos foram mais efetivos para revelar maior número de fragmentos polimórficos de DNA. As duas melhores combinações de "primers" foram EcoR-AAC/Mse-CTT e EcoR-ACT/Mse-CAA, que produziram, sete e onze fragmentos polimórficos de DNA, respectivamente. Em um total de 450 fragmentos de DNA amplificados, pelo menos 339 apareceram bem resolvidos em gel de poliacrílamida corado com prata e 39 bandas polimórficas de DNA foram escrutinadas. O nível de polimorfísmo de DNA (11,5\%) usando apenas oito combinações de "primers" foi efetivo para agrupar biótipos de proso millet em dois clusters, mas insuficiente para separar biótipos híbridos de biótipos selvagens e cultivados. Entretanto, o presente resultado indicou que o método de coloração com prata poderá ser ferramenta barata e importante para estudar relações filogenéticas em proso millet.

Palavras-chave - AFLP, diversidade genética, marcadores moleculares, proso millet

\section{Introduction}

Proso millet (Panicum miliaceum L.) is the major cultivated grain crop in Europe since 2000 BC

\footnotetext{
1. $\quad$ Empresa Brasileira de Pesquisa Agropecuária - Embrapa, Caixa Postal 151, 35701-970 Sete Lagoas, MG, Brazil.

2. Colorado State University, Department of Bioagricultural Sciences and Pest Management, CO 80523, Fort Collins, CO, USA.

3. Colorado State University, Department of Soil Crop Science, CO 80523, Fort Collins, CO, USA.

4. Corresponding author: karam@cnpms.embrapa.br
}

(Anderson \& Martin 1949, Grabouski 1971, Baltensperger 1996) and it is currently cultivated in Eastern Europe, Russia, China, India, and North America. This_crop was first introduced into Canada in the $17^{\text {th }}$ century and in the last 25 years, wild-proso millet has become one of the most aggressive grass weed in North America (Bough et al. 1986, Bough \& Cavers 1987). High infestation by thos weed were first reported in Minnesota and Wisconsin in the early 1970s, and since this period, wild-proso millet has become a serious problem in different regions of the United States and Canada (Strand et al. 1973, WSSA 1992). 
Although it is considered to be a self-pollinated species, about $10 \%$ of cross pollination has been described in natural populations of proso millet (Colosi $\&$ Shaal 1997). Despite of many studies on phenotypic variation and ecological aspects in proso millet populations, their genetic basis was not adequately understood.

Studies applying molecular markers to access genetic variability and phylogenetic relationships in proso millet populations are still limited. In a study carried out by Colosi \& Shaal (1997), within 398 individuals, 97 different genotypes were identified using RAPD markers, being 69 of them identified as wild, 26 crop and feral crop weed and 2 hybrids. In about $10 \%$ of the genotypes, DNA polymorphism suggested hybridization between wild and crop proso millet biotypes.

The Amplified Fragment Length Polymorphism (AFLP) technique (Vos et al. 1995, Blears et al. 1998) has been widely used for genetic studies in many organisms including cultivated plants and its wild relatives (Meksem et al. 1995, Cervera et al. 1996, Hillis et al. 1996, Tohme et al. 1996, Travis et al. 1996, Greef et al. 1997, Paul et al. 1997). Unfortunately, most of the procedures used to detect AFLP markers involve isotopes such as ${ }^{32} \mathrm{P}$ and ${ }^{33} \mathrm{P}$ that are relatively expensive, inconvenient to handle, and potential health hazard. In recent years, the development of nonradioactive methods based in silver stained gels (Cho et al. 1996, Vantoai et al. 1996) or the use of fluorophore labeled primers followed by separation of PCR-amplified products on an automated sequencer apparatus (Goulding et al. 2000, Mortimer \& Arnold 2001) show many advantages over the use of radioisotopes. In both methods, the resolution is greater than that of the ${ }^{32} \mathrm{P}$ labelled gels and a larger number of better-defined bands could be scored. In comparison to other AFLP methods, the fluorescent amplifiedfragment length polymorphism (FAFLP) technique showed a higher resolution of amplicons, thus increasing the number of distinguishable fragments (Arnold et al. 1999, Majeed et al. 2004, Kassama et al. 2006). However, FAFLP still has high start up costs and, for all but least heterogeneous species, fragment analysis requires software not yet freely available for every sequencer (Goulding et al. 2000). The silver staining method could be a choice to overcome these problems in laboratories that do not have those facilities.

The objective of this study was to evaluate the silver staining method to be used for studying genetic diversity of proso millet.

\section{Material and methods}

Three domesticated (South Dakota domestic brown, Colorado domestic white and Colorado domestic orange) and nine wild biotypes (Minnesota-Cambridge wild olive, CanadaRosemount wild black, Oregon-Grand Island wild olive, Ontario Canada-Huron County wild black, NebraskaPanhandle Center wild tan, Wyoming-Platte County wild brown, Colorado-Weld County wild black, Colorado-Weld County wild tan and Colorado wild white) of proso millet (Panicum miliaceum L.) were grown in a growth chamber with a 16 hours photoperiod, $25-20^{\circ} \mathrm{C}$ (day-night temperature), and $50 \%$ relative humidity for two weeks. Eight plants of each biotypes were analyzed.

DNA was extracted from fresh leaves with DNeasy Plant Mini Kit (Qiagen Inc, Valencia, CA). Leaves were ground with liquid nitrogen to obtain approximately $100 \mathrm{mg}$ of fine powder. Cell debris and salt were precipitated using a QIAshredder spin column and the purified DNA was eluted with TE (Tris, EDTA) from a Dneasy spin column. The quality of DNA was checked in $1 \%$ agarose gel, and its concentration was measured by using a spectrophotometer.

The AFLP procedure (Vos et al. 1995) was based on AFLP $^{\text {TM }}$ Analysis System and AFLP Starter Primer protocol (Life Technologies,_Gaithersburg, MD) with some modifications. For restriction digestions, $500 \mathrm{ng}$ of proso millet genomic DNA were digested to completion for $2 \mathrm{~h}$ and $30 \mathrm{~min}$ at $37^{\circ} \mathrm{C}$, with 2.5 units of EcoR I and Mse I restriction enzymes using $2 \mathrm{~mL}$ of the mix of EcoR I and Mse I, in buffer solution (10 mM Tris- $\mathrm{HCl} \mathrm{pH} \mathrm{7.5,} 50 \mathrm{mM} \mathrm{NaCl}, 0.1 \mathrm{mM}$ EDTA, $1 \mathrm{mM}$ DTT, $0.1 \mathrm{mg} / \mathrm{mL} \mathrm{BSA,} \mathrm{50 \% (v/v)} \mathrm{glycerol,} \mathrm{0.1 \%} \mathrm{Triton} \mathrm{X-100).}$ The restriction enzymes were inactivated by heating reaction at $70{ }^{\circ} \mathrm{C}$ for $15 \mathrm{~min}$ and immediately placed on ice for $5 \mathrm{~min}$. Adapters ligation reactions were done with $24 \mu \mathrm{L}$ of adapter ligation solution (5 pmoles EcoR I and 50 pmoles Mse I adapters, $0.4 \mathrm{mM}$ ATP, $10 \mathrm{mM}$ Tris-HCl (pH 7.5), $10 \mathrm{mM} \mathrm{Mg}$-acetate, $50 \mathrm{mM} \mathrm{K}$-acetate), $1 \mu \mathrm{L}$ of $1 \mathrm{U}_{\mu \mathrm{L}^{-1}}$ of $\mathrm{T} 4$ DNA ligase, and incubated at $20^{\circ} \mathrm{C}$ for $2 \mathrm{~h}$. A pre-amplification reaction was made mixing $5 \mu \mathrm{L}$ of ligated DNA, $1 \mu \mathrm{L}$ of $1 \mathrm{U}_{\mu} \mathrm{L}^{-1}$ Taq DNA polymerase, $5 \mu \mathrm{L}$ of $10 \mathrm{X}$ PCR buffer, and $40 \mu \mathrm{L}$ of pre-Amp primer mix, in a final volume of $51 \mu \mathrm{L}$. A 20 cycle $\left(94{ }^{\circ} \mathrm{C}\right.$ for $30 \mathrm{~s}, 52^{\circ} \mathrm{C}$ for $60 \mathrm{~s}, 72^{\circ} \mathrm{C}$ for $60 \mathrm{~s}$ ) PCR was performed for pre-amplification of the DNA template. A dilution to 1:4 $(\mathrm{v} / \mathrm{v})$ of the pre-amplified product was made using TE buffer. All reagents and solutions were obtained in the AFLP Core reagents kit from Life Technologies. EcoR and Mse primers (30 ng each) were mixed with $2 \mu \mathrm{L}$ of the diluted pre-amplified product, $2 \mu \mathrm{L}$ of $10 \mathrm{X} \mathrm{Taq}$ buffer ( $200 \mathrm{mM}$ Tris- $\mathrm{HCl}$ (pH 8.4),

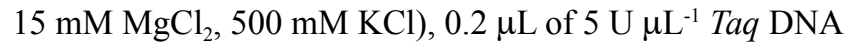
polymerase in a final volume of $20 \mu \mathrm{L}$. The selective amplifications were performed using the following two/three (EcoR-TC/Mse-CAA; EcoR-TG/Mse-CTC), and three/three pairs of primers (EcoR-AAG/Mse-CAA; EcoR-AGG/MseCTT; EcoR-AAG/Mse-CAG; EcoR-AGG/Mse-CTA; EcoRAAC/Mse-CTT; EcoR-ACT/Mse-CAA). The PCR program was: one cycle at $94^{\circ} \mathrm{C}$ for $30 \mathrm{~s} ; 65^{\circ} \mathrm{C}$ for $30 \mathrm{~s}$; and $72^{\circ}$ for $60 \mathrm{~s}$; 
followed by a touch down phase of 13 cycles of $1{ }^{\circ} \mathrm{C}$ lower annealing temperature each cycle. Afterwards, 23 cycles were performed at $94^{\circ} \mathrm{C}$ for $30 \mathrm{~s} ; 56^{\circ} \mathrm{C}$ for $30 \mathrm{~s}$; and $72^{\circ} \mathrm{C}$ for $60 \mathrm{~s}$. The pre and selective amplifications were carried out in a PTC-100 programmable Thermal Controller (MJ Research, Inc, Waltham, MA).

An equal volume of formamide buffer ( $98 \%$ formamide, 10 mM EDTA, pH 8.0, 0,005\% bromophenol blue, 0,005\% xylene cyanol FF for tracking dye) was added to each PCR reaction. The samples were denatured by heating at $95{ }^{\circ} \mathrm{C}$ for $5 \mathrm{~min}$ and then, immediately placed on ice. Five microliters of each sample were loaded on the $5.3 \%$ polyacrylamide gel [acrylamide:bisacrylamide (20:1); $7.5 \mathrm{M}$ Urea; 1X_TBE buffer]. Polyacrylamide gel electrophoresis was performed in a Sequi-Gen $0.04 \times 38 \times 50 \mathrm{~cm}$ apparatus (Bio-Rad Laboratories, Richmond, CA) in $1 \mathrm{X}$ TBE buffer at constant power $(75 \mathrm{~W})$ for $2 \mathrm{~h}$ or $2 \mathrm{~h}$ and $45 \mathrm{~min}$ at $50{ }^{\circ} \mathrm{C}$ with a PC 3000 Power Supply (Bio-Rad Laboratories, Richmount, CA). Samples were run until xylene cyanol was about 2-3 cm from the bottom of the gel.

After electrophoresis, gels were fixed with gentle agitation in $10 \%$ acetic acid for $15 \mathrm{~min}$, followed by three $2 \mathrm{~min}$ water rinse. The silver staining was performed for $30 \mathrm{~min}$ in a solution containing $2 \mathrm{~g}$ silver nitrate; $3 \mathrm{~mL}$ of $37 \%$ formaldehyde in 2 liters water. Afterward, gels were rinsed in water for $10 \mathrm{~s}$ and stain was developed in a solution containing $60 \mathrm{~g}$ of sodium carbonate (Fisher Chemical); $3 \mathrm{~mL}$ formaldehyde; and $400 \mathrm{~mL}$ of sodium thiosulfate (Fisher Chemical). Once bands were visible, the developing process was stopped by adding $10 \%$ acetic acid to the staining solution.

Each polymorphic DNA band on gel was scored as an individual loci by presence (1) or absence (0). Genetic distances were calculated using the complement of the similarity index according to the equations 1 and 2:

$$
S i j=2 a /(2 a+b+c)(\text { Nei \& Li, 1979) }
$$

where $S i j$ is the similarity index between two biotypes, $i$ and $j, a$ is the number of bands present in both $i$ and $j$ biotypes, $b$ is the number of bands present only in the $i$ biotype and $\mathrm{c}$ is the number of bands present only in the $j$ biotype. Conversion to genetic distance ( $G d i j)$ was made by:

$$
G d i j=1-S i j
$$

The genetic distances were used for cluster analysis by dendrogram using the NTSYSpc, version 2.02 for windows (Exeter Software, Setauket, NY). The agglomeration criteria was the UPGMA (unweighted pair-group method with arithmetical averages) (Sneath \& Sokal 1973). The confidence limits of UPGMA-based dendrogram was evaluated by using a 100 repetition bootstrap analysis (Hillis \& Bull 1993) with GQMOL program (Cruz 1999).

\section{Results and Discussion}

A high resolution silver stained polyacrylamide gel without radioactive isotopes revealed to be an efficient technique to visualize AFLP markers in proso millet (figure 1). Silver-staining method shows many advantages in relation to standard radioactive procedure because it reduces time and costs as well as eliminates hazardous of working with radioisotopes (Vantoai et al. 1996, Chalhoulb et al. 1997). Eight combinations of AFLP primers were used for checking reproducibility and the resolution power of the silver staining method. At least 450 amplified fragments could be observed in polyacrilamide gels and some bands were difficult to be scored. Of the total bands, 339 were clearly separated on gels and 39 polymorphic DNA fragments (11.5\%) were easily identified. Vos et al. (1995) reported that radiolabeled restriction fragments amplified by AFLP detect 50 to 100 fragments on a polyacrylamide gel. In the present study with proso millet an average of 56 amplified fragments were obtained per reaction, indicating that silver stained polyacrylamide gel retains the resolution power of the radiolabeled technique.

Although combination of primers with two and three selective nucleotides produced more amplified DNA fragments (figure 1A) than the combination of three and three selective nucleotides (figure 1B) those bands were difficult to be screened. Among primer combinations, EcoR-AAC/Mse-CTT and EcoR-ACT/ Mse-CAA provided more information, producing seven and eleven polymorphic fragments, respectively (figure 1B, table 1). According to Blears et al. (1998), AFLP primers with only one or two selective nucleotide are necessary for revealing polymorphism in organisms with small genome size $\left(10^{6}-10^{7} \mathrm{bp}\right)$, while additional selective nucleotides are required for those organisms with larger genomes $\left(10^{8}-10^{10} \mathrm{bp}\right)$. In the present study, results with proso millet, a species with small genome $\left(10^{6} \mathrm{bp}\right)$, primers with two selective nucleotides were unable to reveal polymorphism between 12 biotypes (data not shown). On the other hand, primers combination with three selective nucleotides produced eight polymorphic fragments on average (figure 1B). The level of polymorphism per primer pair combination (11.5\% on average) indicates that the AFLP may be useful for studying intraspecific variation and genetic relationships among proso millet biotypes.

UPGMA cluster analysis (Nei \& Li 1979) using AFLP markers of twelve proso millet previously classified as wild and domesticated biotypes produced two groups without apparent relationships among wild and domesticated biotypes and was confirmed by the confidence test of bootstrap (figure 2). Six wild proso millet biotypes (Minnesota-Cambridge wild olive, Canada-Rosemount wild black, Oregon-Grand Island 
wild olive, Colorado Weld County wild black, Colorado wild white and Ontario Canada-Huron County wild black) were clustered with domesticated plants. However, those biotypes could not be considered as standard of wild type since they show many phenotypic characters of domesticated plants like, non-dormancy and a relative high rate of radicle development during seed germination (Karam 2000). Previous studies considering ecophysiological traits (Striegel \& Boldt 1981, Eberlein et al. 1990, Westra \& Callan 1990, Karam 2000) concluded that all these six biotypes were intermediate between wild and domesticated populations with Minnesota Cambridge showing less weed characteristics than the other five wild biotypes.
A

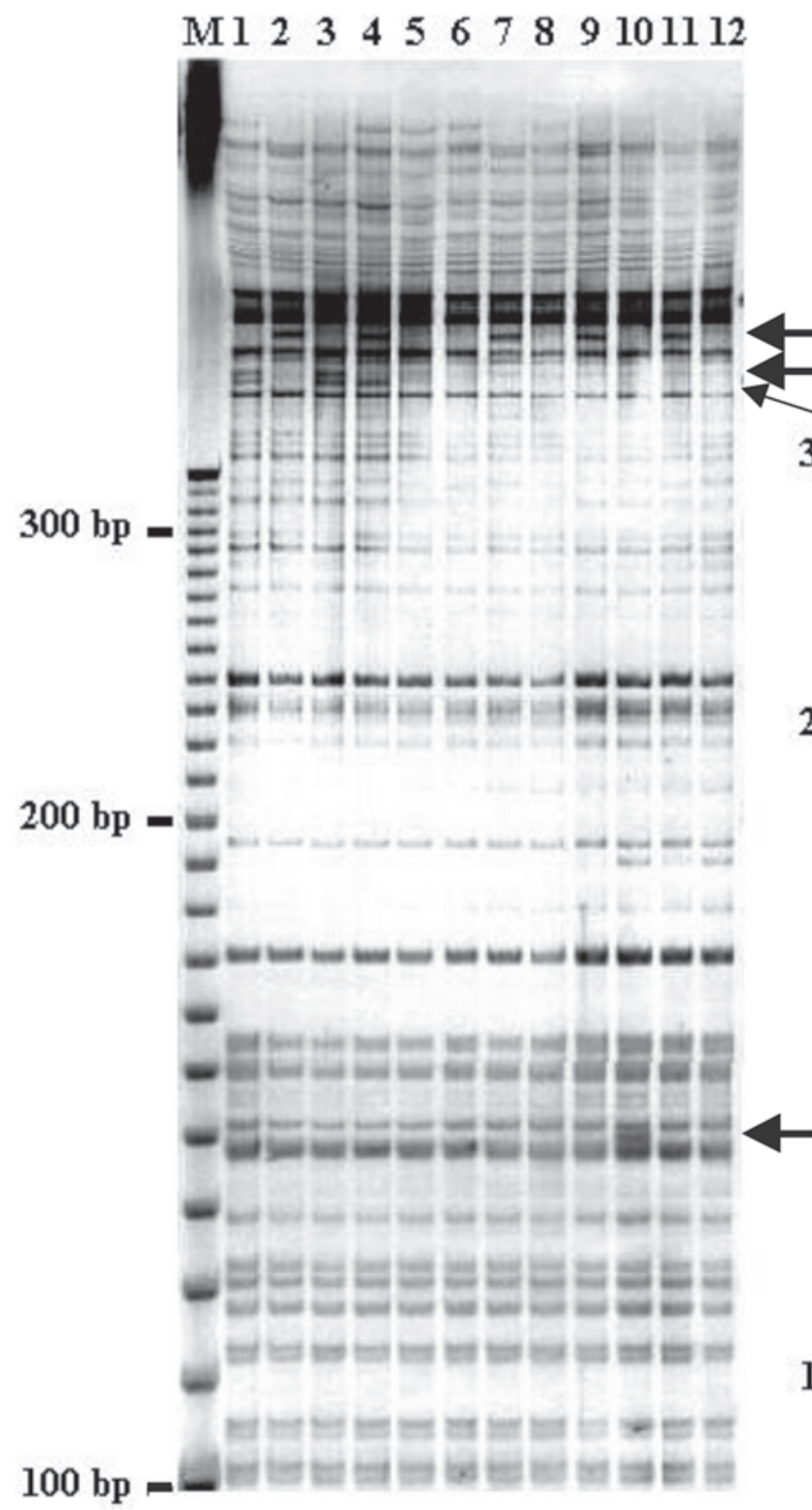

B

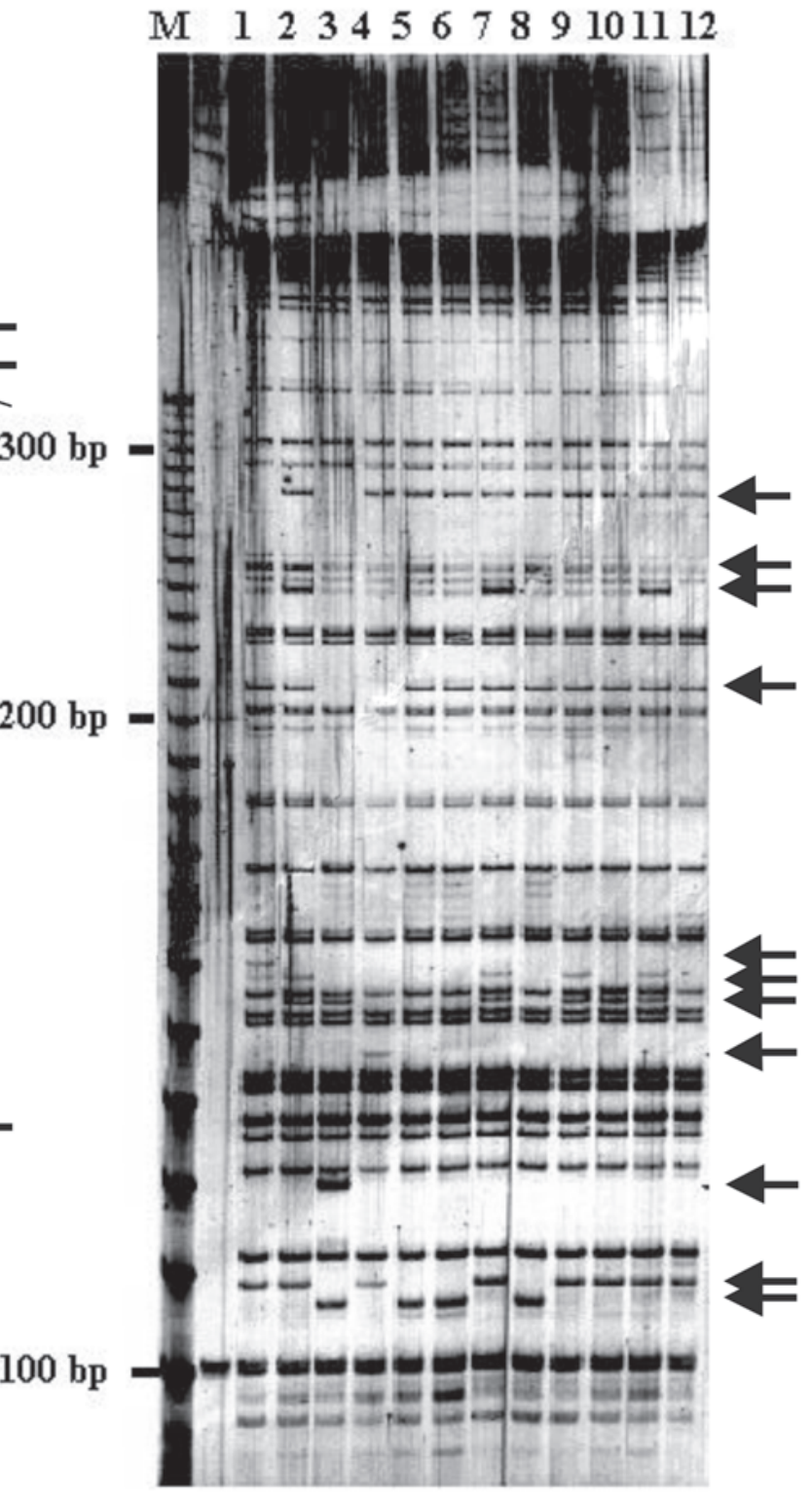

Figure 1. AFLP pattern of twelve proso millet (Panicum miliaceum L.) biotypes derived of the primer combination EcoR-TC/Mse-CAA (A) and EcoR-ACT/Mse-CAA (B). Numbers 1 to 12 on gel correspond to seeded biotypes: Minnesota-Cambridge wild olive; Canada-Rosemount wild black; Oregon-Grand Island wild olive; Ontario Canada-Huron County wild black; Nebraska-Panhandle Center wild tan; Wyoming-Platte County wild brown; Colorado-Weld County wild black; Colorado-Weld County wild tan; South Dakota domestic brown; Colorado domestic white; Colorado domestic orange, and Colorado wild white, respectively. Polymorphic bands are indicated by arrows. $\mathrm{M}=\mathrm{a} 10 \mathrm{bp}$ molecular marker (Invitrogen co., Carlsbad, Ca). 
Table 1. Primer combinations of AFLP reactions and genetic diversity indexes for wild and domesticated proso millet (Panicum miliaceum L.) biotypes.

\begin{tabular}{|c|c|c|c|c|c|}
\hline \multirow[t]{2}{*}{ Primer combination } & \multirow[t]{2}{*}{ Total number of bands } & \multicolumn{2}{|c|}{ Polymorphic bands } & \multicolumn{2}{|c|}{ Genotype unique bands } \\
\hline & & Number & $\%$ & Number & $\%$ \\
\hline EcoR-TC/Mse-CAA & 54 & 4 & 7.41 & 1 & 25.0 \\
\hline EcoR-TG/Mse-CTC & 56 & 0 & - & 0 & - \\
\hline EcoR-AAG/Mse-CAA & 37 & 5 & 13.51 & 0 & - \\
\hline EcoR-AGG/Mse-CTT & 41 & 4 & 9.76 & 1 & 25.0 \\
\hline EcoR-AAG/Mse-CAG & 43 & 4 & 9.30 & 1 & 33.3 \\
\hline EcoR-AGG/Mse-CTA & 34 & 4 & 11.76 & 2 & 50.0 \\
\hline EcoR-AAC/Mse-CTT & 39 & 7 & 17.95 & 3 & 42.86 \\
\hline EcoR-ACT/Mse-CAA & 35 & 11 & 31.43 & 3 & 27.27 \\
\hline Total & 339 & 39 & - & 11 & - \\
\hline
\end{tabular}

Afterwards, RAPD analysis (Colosi \& Schaal 1997) demonstrated that Minnesota Cambridge was a genetically intermediary between wild and domesticated biotypes and probably originated by hybridization among them.

Based in AFLP markers, two wild biotypes (Minnesota-Cambridge wild olive and Ontario CanadaHuron County wild black) and one domesticated biotype (Colorado domestic orange) are genetically intermediary between wild (group two) and other domesticated biotypes in group one. The data suggest that hybridization of these three biotypes with wild and domesticated proso

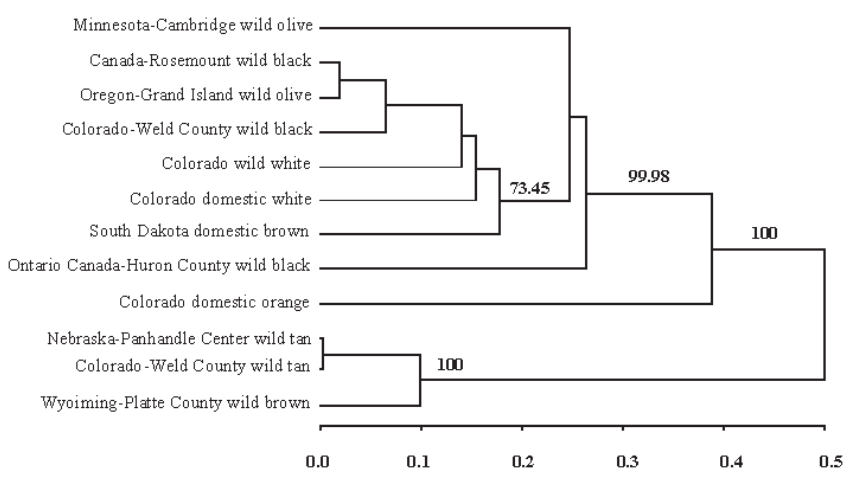

Figure 2. Dendrogram reporting AFLP-based genetic relationships among twelve proso millet (Panicum miliaceum L.) biotypes. The length of horizontal branches are proportional to genetic distance among biotypes while vertical branches are arbitrary. Numbers in $x$-axis correspond to genetic distances and values on branches indicate the number of times (expressed as percentage) that genotypes were joined together with a 100 cycles of bootstrap analysis (Cruz 1999). Dendrogram was generated with NTSYSpc software, version 2.2 (Exeter Software co., Setauket, NY). millet could be a more recent event compared with other members of group one (Canada-Rosemount wild black, Oregon-Grand Island wild olive, Colorado-Weld County wild black, Colorado wild white, Colorado domestic white and South Dakota domestic brown). The second AFLP group was constituted by Nebraska-Panhandle Center wild tan, Colorado-Weld County wild tan and Wyoming-Platte County wild brown. Studies based on phenotypic observations concluded that these biotypes were wild types without any trace of cultivated plants and may represent genuine wild proso millet biotypes (Karam 2000).

The present result with AFLP markers is in accordance with previous studies in proso millet using RAPD markers (Colosi \& Schaal 1997) and phenotypic parameters (Striegel \& Boldt 1981, Eberlein et al. 1990, Westra \& Callan 1990, Karam 2000) and demonstrated the usefulness of silver staining method for revealing AFLP markers for studying genetic diversity in proso millet.

Acknowledgements - Financial support was provided by the Empresa Brasileira de Pesquisa Agropecuária, Embrapa.

\section{References}

ANDERSON, E. \& MARTIN, J.D. 1949. World production and consumption of millet and sorghum. Economic Botany 3:265-288.

ARNOLD, C., METHERELL, L., WILLSHAW, G., MAGGS, A. \& STANLEY, J. 1999. Predictive fluorescent amplifiedfragment length polymorphism analysis of Escherichia coli: high-resolution typing method with phylogenetic significance. Journal of Clinical Microbiology 37:1274-1279. 
BALTENSPERGER, D.D. 1996. Foxtail and proso millet. In Progress in new crops (J. Janick, ed.). ASHS Press, Alexandria, p.182-190.

BLEARS, M.J., DE GRANDIS, S.A., LEE, H. \& TREVORS, J.T. 1998. Amplified fragment length polymorphism (AFLP): a review of the procedure and its application. Journal of Indian Microbiology and Biotechnology 21:99-114.

BOUGH, M.J. \& CAVERS, P.B. 1987. Proso millet. Ministry of agriculture and Food, Ontario, Factsheet, v.87.

BOUGH, M., COLOSI, J.C. \& CAVERS, P.B. 1986. The major weedy biotypes of proso millet (Panicum miliaceum) in Canada. Canadian Journal of Botany 64:1188-1198.

CERVERA, M.T., GUSMAO, J., STEENACKERS, M., GYSEL, A. VAN., MOTANGU, M. VAN \& BOERJAN, W. 1996. Amplification of AFLP based molecular markers to breeding of Populus spp. Plant Growth Regulators 20:47-52.

CHALHOULB, B.A., THIBAULT, S., LAUCOU, V., RAMEAU, C., HÖFTE, H. \& COUSIN, R. 1997. Silver staining and recovery of $\mathrm{AFLP}^{\mathrm{TM}}$ amplification products on large denaturing polyacrylamide gels. Biotechniques 22:216-220.

CHO, Y.C., BLAIR, M.W., PANAUD, O. \& MCCOUCH, S.R. 1996. Cloning and mapping of variety-specific rice genomic DNA sequences: amplified fragment length polymorphism (AFLP) from silver-stained polyacrylamide gels. Genome 39:373-378.

COLOSI, J.C. \& SHAAL, B.A. 1997. Wild proso millet (Panicum miliaceum) is genetically variable and distinct from crop varieties of proso millet. Weed Science 45:509-518.

CRUZ, C.D. 1999. Programa GQMOL: análise de dados moleculares e associação com caracteres quantitativos. Software. Universidade Federal de Viçosa, Viçosa.

EBERLEIN, C.V., LURVEY, E.L., MILLER, T.L. \& MICHAEL, J.L. 1990. Growth and development of wild proso millet (Panicum miliaceum) biotypes. Weed Technology 4:415-419.

GOULDING, J.N., STANLEY, J., SAUNDERS, N. \& ARNOLD, C. 2000. Genome-sequence-based fluorescent amplifiedfragment length polymorphism analysis of Mycobacterium tuberculosis. Journal of Clinical Microbiology 38:1121-1126.

GRABOUSKI, P.H. 1971. Selective control of weeds in proso millet with herbicides. Weed Science 19:207-209.

GREEF, J.M., DEUTER, M., JUNG, C. \& SCHONDELMAIER, J. 1997. Genetic diversity of European Miscanthus species revealed by AFLP fingerprinting. Genetic Resource in Crop Evolution 44:185-195.

HILLIS, D.M. \& BULL, J.J. 1993. An empirical test of bootstrapping as a method for assessing confidence in phylogenetic analysis. Systematic Biology 42:182-192.
HILLIS, D.M., MABLE, B.K. \& MORITZ, C. 1996. Applications of molecular systematics: The state of the field and a look to the future. In Molecular systematics, (D.M. Hillis, B.K. Mable \& C. Moritz, eds.), Sinauer Associates, Sunderland, p.515-543.

KARAM, D. 2000. Wild proso millet (Panicum miliaceum L.): Growth analysis, competitive ability and genetic variation. $\mathrm{PhD}$ thesis, Colorado State University, Fort Collins.

KASSAMA, Y., SHEMKO, M., SHETTY, N., FANG, Z., MACINTIRE, G., GANT, V., ZUMLA, A. \& GOODACRE, R. 2006. An improved fluorescent amplified fragment length polymorphism method for typing Mycobacterium tuberculosis. Journal of Clinical Microbiology 44:288-289.

MAJEED, A.A., AHMED, N., RAO, K.R., GHOUSUNNISSA, S., KAUSER, F., BOSE, B., NAGARAJARAM, H.A., KATOCH, V.M., COUSINS, D.V., SECHI, L.A., GILMAN, R.H. \& HASNAIN, S.E. 2004. AmpliBASE MT: a Mycobacterium tuberculosis diversity knowledgebase. Bioinformatics 20:989-992.

MEKSEM, K., LEISTER, D., PELEMAN, J., ZABEAU, M., SALAMINI, M. \& GEBHARDT, C. 1995. A highresolution map of the vicinity of the $\mathrm{R} 1$ locus on chromosome $\mathrm{V}$ of potato based on RFLP and AFLP markers. Molecular and General Genetics 249:74-81.

MORTIMER, P. \& ARNOLD, C. 2001. FALP: last word in microbial genotyping? Journal of Medical Microbiology 50:393-395.

NEI, M. \& LI, W.H. 1979. Mathematical model for studying genetic variation in terms of restriction endonucleases. Proceedings of the Natural Academic Science 76:5269-5273.

PAUL, S., WACHIRA, F.N., POWEL, W. \& WAUGH, R. 1997. Diversity and genetic differentiation among populations of Indian and Kenyan tea (Camellia sinensis (L.) O. Kuntze) revealed by AFLP markers. Theoretical and Applied Genetics 94:255-263.

SNEATH, P.H.A. \& SOKAL, R.R. 1973. Numerical taxonomy: The principles and practice of numerical classification. W. H. Freeman and Company, San Francisco.

STRAND, O.E., BEHRENS, R. \& MILLER, G.R. 1973. Wild proso millet, Panicum miliaceum L., a new weed problem in Minnesota. Proceedings of the North Central Weed Control Conference, Saint Louis, p.51-52.

STRIEGEL, W.L. \& BOLDT, P.F. 1981. Germination and emergence characteristics of wild proso millet. Proceedings of the North Central Weed Control Conference, Des Moines, p.22.

TOHME, J., GONZALES, D.O., BEEBE, S. \& DUQUE, M.C. 1996. AFLP analysis of gene pools of a wild bean core collection. Crop Science 36:1375-1384.

TRAVIS, S.E., MASCHINSKI, J. \& KEIN, P. 1996. An analysis of genetic variation in Astragalus cremnophylax var. cremnophylax, a critically endangered plant, using AFLP markers. Molecular Ecology 5:735-745. 
VANTOAI, T.T., PENG, J.Q. \& MARTIN, S. 1996. Optimization of silver-staining AFLP technique for soybean. Soybean Genetic Newsletter 23:206-209.

VOS, P., HOGERS, R., BLEEKER, M., REIJANS, M., VANDELEE, T., HORNES, M., FRIJTERS, A., POT, J., PELEMAN, J., KUIPER, M. \& ZABEAU, M. 1995. AFLP: a new technique for DNA fingerprinting. Nucleic Acids Research 23:4407-4414.
WESTRA, P. \& CALLAN, M. 1990. Morphological and reproductive characteristics of fifteen wild proso millet (Panicum miliaceum) accessions from the United States and Canada. Research Program Report, Western Society of Weed Science, Reno, p.405-407.

WSSA. 1992. Crop losses due to weeds in the United States. Weed Science Society of America, Champaign, p.75-147. 